\section{Gammel traver imponerer fortsatt}

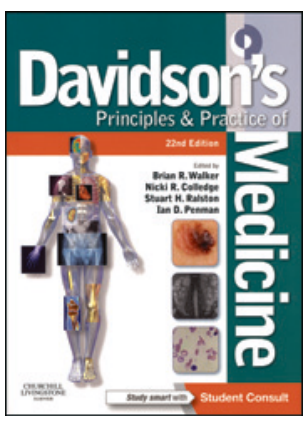

Brian R. Walker, Nicki R. Colledge,

Stuart H. Ralston et al, red.

Davidsons's principles and practice of medicine

22. utg. 1372 s, tab, ill. Edinburgh: Churchill

Livingstone Elsevier, 2014. Pris USD 86

ISBN 978-7020-5035-0

De fleste bøker som kommer i 22. utgave vil borge for en viss grad av kvalitet, bare på grunn av det. Davidson's principles and practice of medicine vil være kjent i ulike utgaver for de aller fleste av dagens praktiserende leger i Norge, med første utgave tilgjengelig allerede i 1952.

De to hovedbolkene er en fagovergripende del, «principles of medicine» (immunologi, genetiske faktorer), og en hovedbolk hvor man tar for seg de mer tradisjonelle emnene $\mathrm{i}$ indremedisin (21 kapitler). Inndeling og oppbygging er lett gjenkjennelig: moderat men tilstrekkelig - omfang av figurer, men rikelig med små tabeller. «Learning points» og kapittelsammendrag mangler. Derimot er det tatt inn såkalte bokser («boxes») med spesifikke momenter knyttet til geriatri, svangerskap og oppvekst («adolenscence»). I hvert kapittel er det også en kort liste over annen anbefalt litteratur samt referanse til aktuelle internettressurser.

Boken inneholder en kode for tilgang til elektronisk utgave (via studenconsult.com), men har foreløpig ingen apputgave. Det foreligger også flere andre bøker, kliniske kasuistikker, kortversjon av boken, klinisk undersøkelsesteknikk osv., som er nært knyttet til denne hovedboken.

Det er lite å utsette. Boken har etablert seg som en av referansebøkene innenfor generell indremedisin, og har maktet å modernisere seg både med hensyn til innhold, form og elektroniske koblinger. Norsk medisinsk praksis skiller seg fortsatt på enkelte punkter fra engelsk (skotsk) praksis, men på dette nivået er disse ulikhetene lite fremtredende.

I mangel på rene norske indremedisinske lærebøker er det uproblematisk å anbefale dette som ett av de beste læreverkene for medisinstudenter. Mange praktiserende leger vil også ha glede av en så komplett referansebok. Google-søk har fortsatt ikke erstattet behovet for kvalifiserte lærebøker.

\section{Lars Aabakken}

Overlege, Avdeling for transplantasjonsmedisin

Oslo universitetssykehus, Rikshospitalet

\section{Kan vi lære av andres feil?}

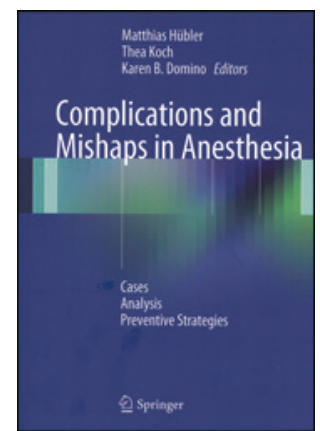

Matthias Hübler, Thea Koch,

Karen B. Domino, red.

Complications and mishaps in anesthesia

Cases - Analysis - Preventive strategies.

365 s, tab, ill. Heidelberg: Springer, 2015

Pris EUR 51

ISBN 978-3-642-45407-3

Ingen er uenige i sir Liam Donaldsons utsagn om at selv om det er menneskelig å feile, er det uakseptabelt å dekke over, og helt utilgivelig ikke å lære av hendelser. Likevel famler vi fortsatt $\mathrm{i}$ blinde når det gjelder å designe et effektivt system for tilbakemelding og læring. Noen har klokketro på at løsningen ligger i databaserte registerløsninger, mens andre sverger til elektroniske kvalitetshåndbøker. Tross dette gjentar alvorlige og utilsiktede hendelser med pasientskade seg, dessverre også i samme avdeling. Finnes det en løsning som vi ikke har sett? Slik at vi kan skape den «lærende organisasjonen» vi så gjerne ønsker?

Forfatterne er åpenbart av den oppfatning og har tatt mål av seg til å lage en bok med en variert samling av 33 pasienthistorier. Hver hendelse er beskrevet som en situasjon hvor en pasient skal gjennomgå en prosedyre med anestesiologisk relevans, hvor det så skjer en uønsket hendelse. Tiltak og vurderinger beskrives, avbrutt av relevante faglige momenter og det endelige resultatet, både for pasienten og anestesilegen. Forfatterne gir så sin dom over hva som ble gjort feil i hvert enkelt tilfelle.

Historier har potensial for å gi mer læring enn kun tørre tall og tradisjonell læreboktilnærming for skaderisikoen i vårt fag. Anmelderen synes således at forfatterne har lykkes med å skrive en ganske interessant bok med historier som vi kan kjenne oss igjen i. Det litterære grepet de har valgt, hvor de omtaler personene med fiktive navn, gir kanskje litt mer realisme. Ikke alle er like gode, men det gjør ikke så mye. Hovedhensikten er jo at leseren kan sette seg mer inn i hendelsen og de mange medvirkende faktorene. Tabellen bakerst, der historiene er sortert etter de psykologiske faktorene, er god, likeledes referansene i hvert kapittel. Layouten er også grei, og boken er ganske lettlest med både tabeller, flytskjema og bilder. Disse er av litt varierende kvalitet, men stort sett bra.

Spørsmålet er om boken er relevant for norske forhold? Det amerikanske systemet er litt annerledes enn vårt, men de kliniske problemstillingene og de valgene vi står overfor, er jo de samme.

Boken er en litt annerledes tilnærming til et viktig tema, men brukt som grunnlag for internundervisning og kombinert med egne erfaringer vil den kunne fungere utmerket. Jeg anbefaler den.

Guttorm Brattebø

Avdelingsoverlege, Akuttmedisinsk avdeling KSK

Haukeland universitetssykehus 